\title{
Cohort Analysis of Death from Malignant Neoplasms in Japan
}

\author{
Kiyomi Aoyama, Takero Kaido, Yoshihiko Miura, Keiko Nakazaki, \\ Megumu Kato, Iwao Uchiyama, Kuniaki Kitamura, \\ Masako Naito, Yukitaka Endo and Tatsuo Negishi \\ Department of Adult Health, Faculty of Medicine, University of Tokyo, Tokyo
}

\section{INTRODUCTION}

A number of medical and biological reports have been published on the nature of malignant neoplasms ${ }^{1 \sim 18)}$, and some studies have been completed on the etiology and pathogenesis of a few diseases that include some occupational neoplasms ${ }^{9,10)}$, and experimental neoplasms ${ }^{12 \sim 15)}$. An analysis of occupational neoplasms should provide indications as to whether a group exposed to "specific" agents ${ }^{16,17}$ ) would be prone to develop neoplasms. Therefore, we have made a cohort analysis of deaths caused by malignant neoplasms in Japan.

Since Susser published his study on the peptic ulcer ${ }^{19)}$, there have been many papers on cohort analysis and especially on the cohort phenomenon of many diseases ${ }^{20 ~ 31)}$. The cohort phenomenon is usually defined as follows; a group exposed to an agent such as an air attack may run a considerable stationary death risk for several years after exposure, i.e. some people in the same chronological age group tend to face a special type of death risk due to exposure to the disease of their group. Thus, a cohort analysis should show a transition in the nature of a disease and its relationship to people.

\section{MATERIALS}

The materials used in this paper are "Jinko-dotai-tokei" ("Vital Statistics Japan") 1965-1975, edited by "Kosei-sho-daijinkanbo-tokei-joho-bu" ("Health and Welfare Statistics and Information Department, Minister's Secretariat. Ministry of Health and Welfare Japan").

\section{METHODS}

A cohort analysis was made on the basis of a 5 -year period and a 5 -year difference in age. Analyses of malignant neoplasms by site were made from 1950 to 1975.

We used the X-Y plotter, in the System of the $8,800 / 8,700$ computer, at the Computer Center of the University of Tokyo, to trace the death rates, except for the schemata.

\section{RESULTS AND DISCUSSION}

Fig. 1-1 shows the cohort analysis of the death rates for malignant neoplasms in total sites, in males, from 1920 to 1975. Small numbers in the figure show each cohort born during the period shown in Table 1 . The death rate for the oldest age group has been steadily rising since the beginning of 1920 . The figure shows an increase among the members of the younger age groups.

Based on the time period used in Fig. 1-1, Fig. 1-2 shows the cohort analysis of the death rates for malignant neoplasms for 5-year age groupings. Fig. 1-3 shows the schema 

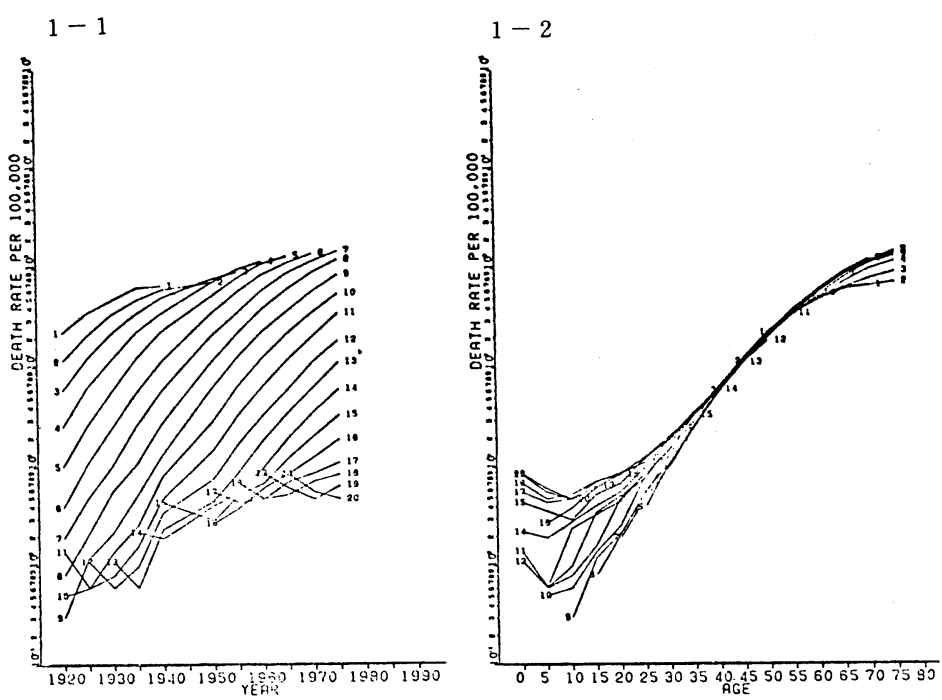

$$
1-3
$$

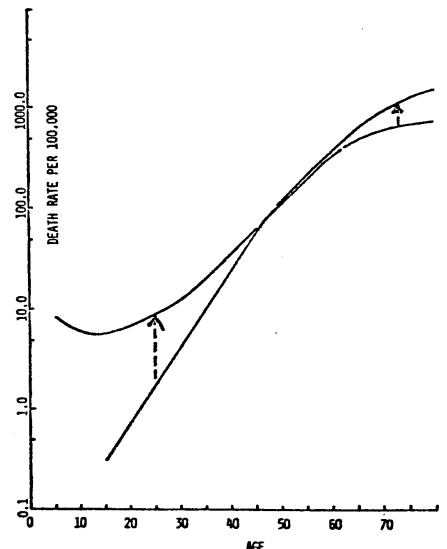

Fig. 1 Cohorts of death from malignant neoplasms (male)
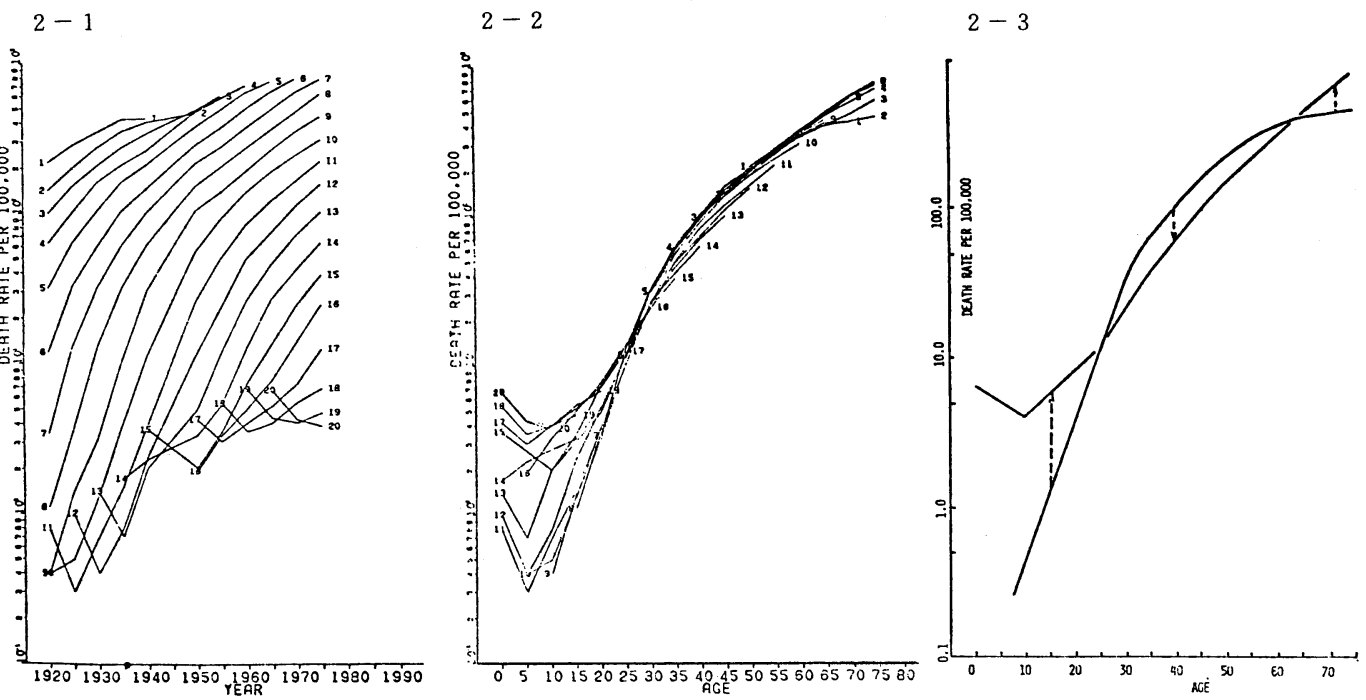

Fig. 2 Cohorts of death from malignant neoplasms (female)

for Fig. 1-2. The death rate is increasingly higher among the older and younger age groups during the same period, and makes the age-specific death rate curve flatten out. This means that there is a transition in the nature of the disease from "specific" to "nonspecific" in an age group. Figs. 2-1 and 2-2 are the analyses for females; they show almost the same patterns as males. Fig. $2-3$ is the schema for Fig. 2-2. Slight decreasing transitions can be detected in females though a rectilinear age-specific death rate curve has been formed.

Figs. 3-1 and 3-2 show the analyses of stomach cancer. The small numbers in the figure are for cohorts born during the period shown in Table 2. There is a gradual decrease in the death rate in the middle and older age groups and the trend has yet to abate. 
Table 1 Birth year of each cohort for Fig. 1 and Fig. 2

\begin{tabular}{c|c||c|c}
\hline Cohorts & Birth year & Cohorts & Birth year \\
\hline 1 & $1866 \sim 1870$ & 11 & $1916 \sim 1920$ \\
2 & $1871 \sim 1875$ & 12 & $1921 \sim 1925$ \\
3 & $1876 \sim 1880$ & 13 & $1926 \sim 1930$ \\
4 & $1881 \sim 1885$ & 14 & $1931 \sim 1935$ \\
5 & $1886 \sim 1890$ & 15 & $1936 \sim 1940$ \\
6 & $1891 \sim 1895$ & 16 & $1941 \sim 1945$ \\
7 & $1896 \sim 1900$ & 17 & $1946 \sim 1950$ \\
8 & $1901 \sim 1905$ & 18 & $1951 \sim 1955$ \\
9 & $1906 \sim 1910$ & 19 & $1956 \sim 1960$ \\
10 & $1911 \sim 1915$ & 20 & $1961 \sim 1965$ \\
\hline
\end{tabular}

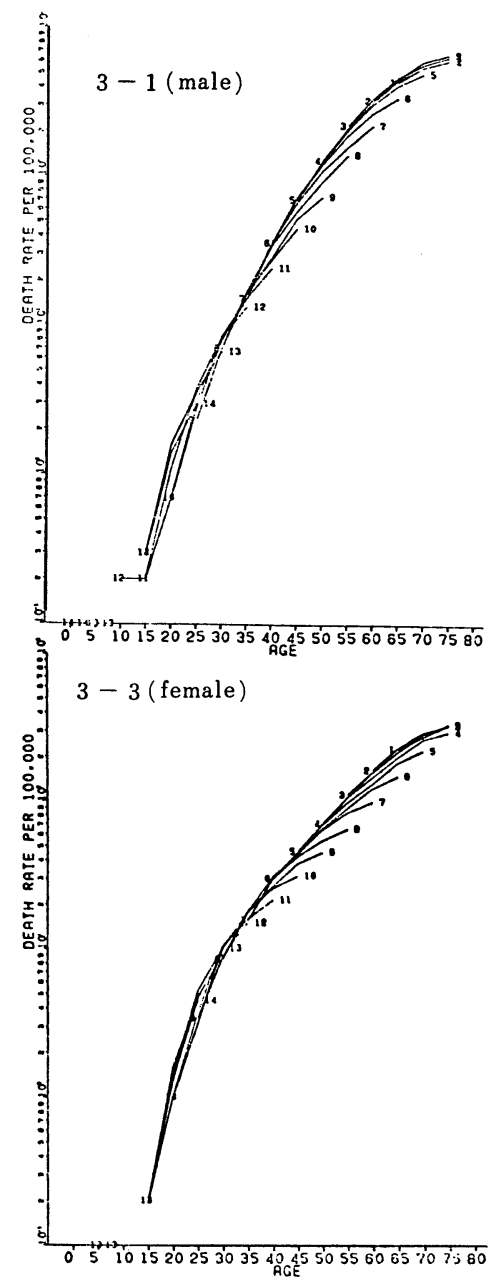

Table 2 Birth year of each cohort for Figs. 2 99

\begin{tabular}{c|c||c|c}
\hline Cohorts & Birth year & Cohorts & Birth year \\
\hline 1 & $1881 \sim 1885$ & 11 & $1931 \sim 1935$ \\
2 & $1886 \sim 1890$ & 12 & $1936 \sim 1940$ \\
3 & $1891 \sim 1895$ & 13 & $1941 \sim 1945$ \\
4 & $1896 \sim 1900$ & 14 & $1946 \sim 1950$ \\
5 & $1901 \sim 1905$ & 15 & $1951 \sim 1955$ \\
6 & $1906 \sim 1910$ & 16 & $1956 \sim 1960$ \\
7 & $1911 \sim 1915$ & 17 & $1961 \sim 1965$ \\
8 & $1916 \sim 1920$ & & \\
9 & $1921 \sim 1925$ & & \\
10 & $1926 \sim 1930$ & & \\
\hline
\end{tabular}
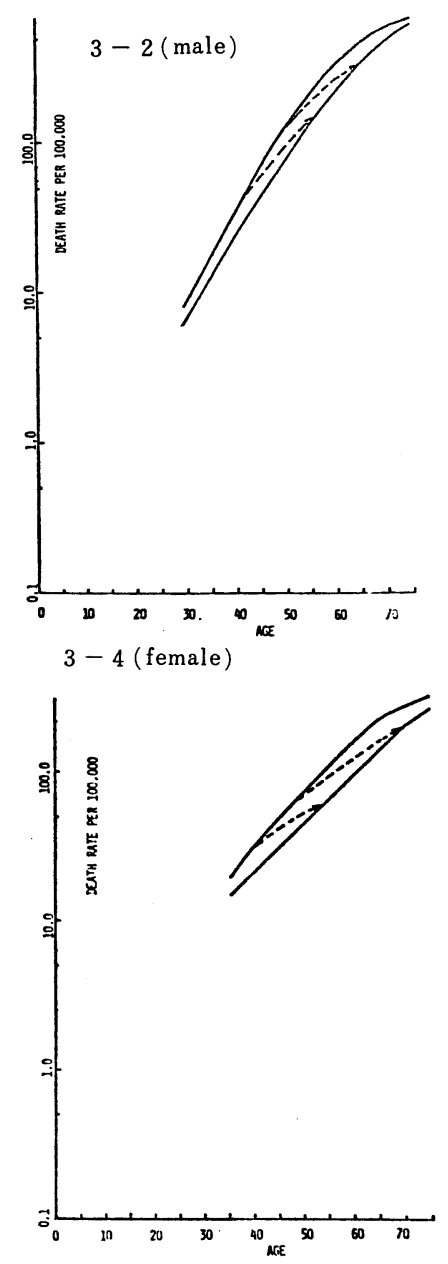

Fig. 3 Cohorts of death from stomach cancer 
Figs. 3-3 and 3-4 are analyses of stomach cancer in females; a similar tendency is shown.

Figs. 4-1 and 4-2 are analyses of lung cancer in males. Death rates increase rapidly in almost all the age groups shown. There is a trend for a smaller increase among the later groups that seems to be closer to the final rectilinear formation of the age-specific death rate curve. Figs. 4-3 and 4-4 show the analyses for females. We concluded that the increasing death rate among females has ended as shown by the rectilinear age-specific death rate curve (line).

Fig. 5-1 shows the analysis of liver cancer in males. There was no major change in the period. Fig. 5-2 is the analysis for females. Here, the cohort phenomenon is on the decrease in the 25-29 age group and above, and the death rate will become considerably lower in the future. Why the phenomenon was seen only in females is a pressing problem that must be solved. Careful observation showed and accelerating or increasing trend at the beginning of 1950 and 1960. Fig. 5-3 is the schema for Fig. 5-2.

Fig. 6-1 and 6-2 show the cohort analyses for pancreas cancer in males. An increasing
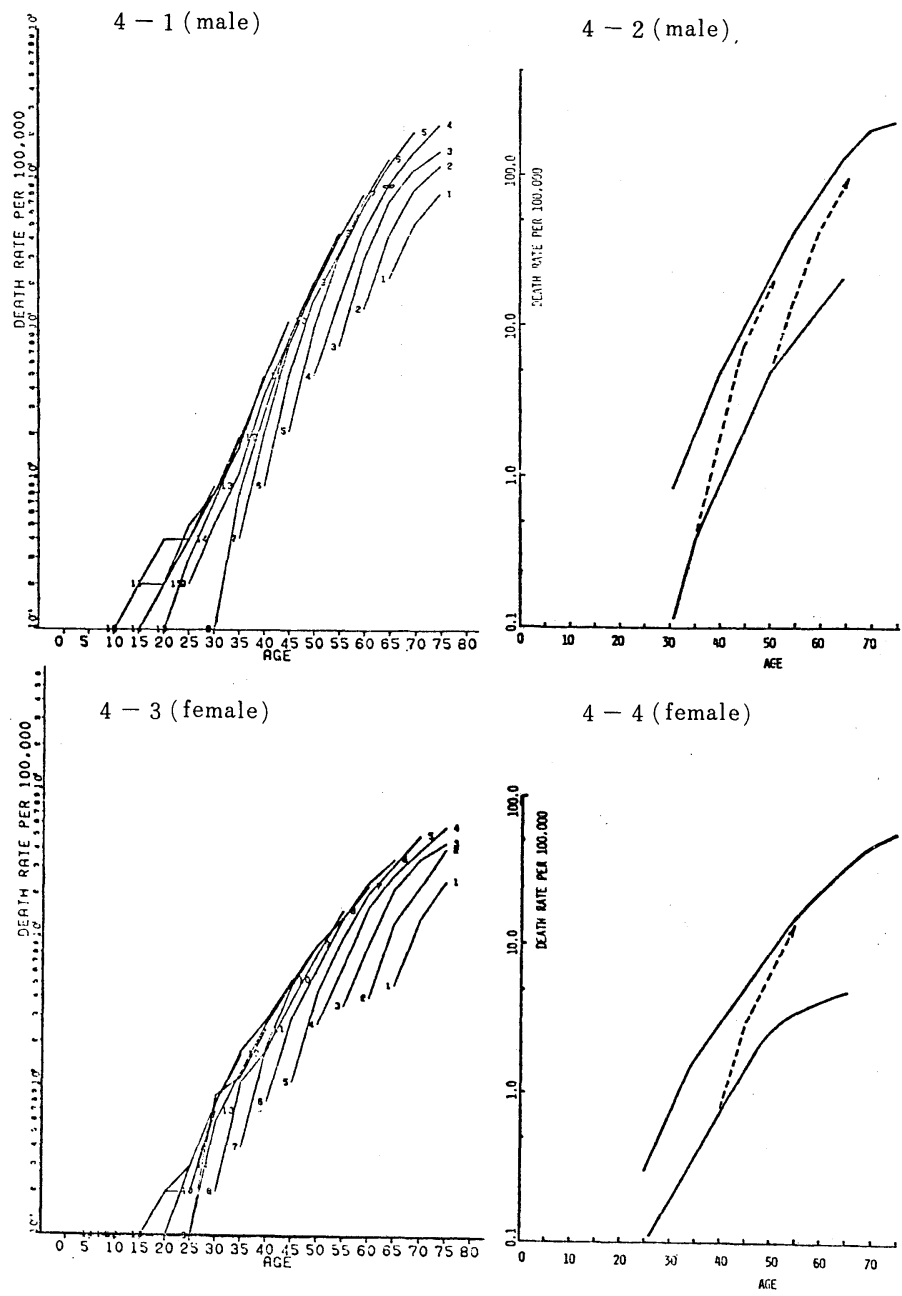

Fig. 4 Cohorts of death from lung cancer 
$5-1$ (male)

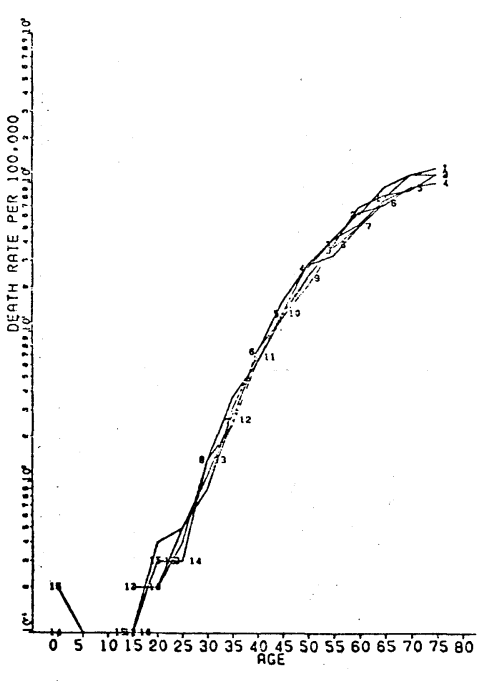

$5-2$ (female)

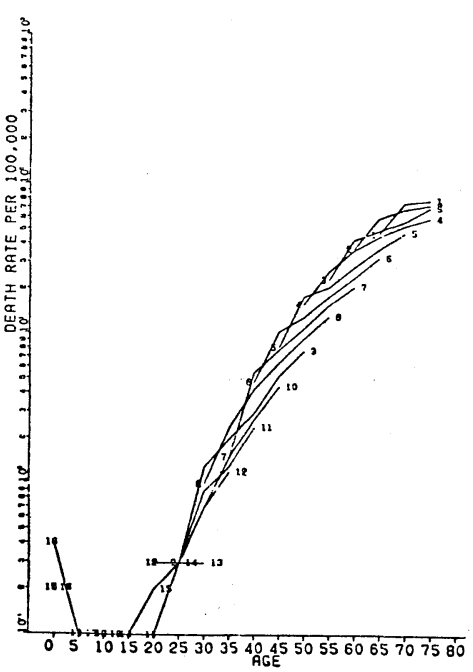

$5-3$ (female)

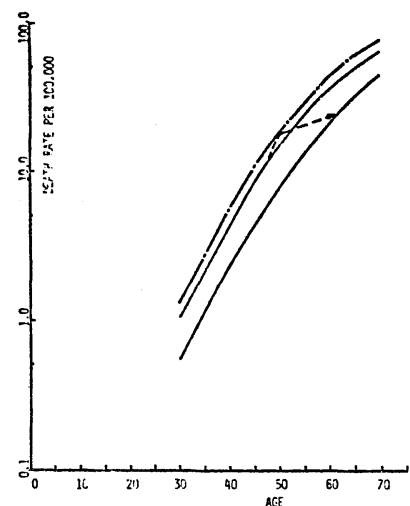

Fig. 5 Cohorts of death from liver cancer

cohort phenomenon that is gradually becoming smaller is shown with a final age-specific death rate curve. Figs. 6-3 and 6-4 are analyses for females. The same cohort phenomenon appears here.

Figs. 7-1,7-2, 7-3 and 7-4 show the analyses of leukemia, in males and in females. The cohort phenomena occur in both sexes. The final death rate curves are already given, but the final age-specific death rate curves show gentle slopes.

Fig. 8 is the analysis of breast cancer in females. There is a special, stationary death rate pattern after the climacterium.

Figs. 9-1 and 9-2 show the analyses of uterus cancer. There is a distinct cohort phenomenon in terms of the decreasing death rate. This death rate is likely to be far lower in the future.

In summary, changes in the death rates caused by neoplasms at particular sites could be divided into two major categories: category-I those showing the cohort phenomena, and category-II those showing no cohort phenomena during the observation period; e.g. breast cancer in females and liver cancer in males.

Category-I could be divided into four types:

"Type I": The decreasing cohort phenomenon; i.e. stomach cancer in both sexes and uterus cancer in females.

"Type II": The two-phase cohort phenomenon; first increasing, then decreasing, i.e. liver cancer in females.

"Type III": The increasing cohort phenomenon in lung and pancreas cancers in both sexes. Immediate health control measure are needed against these diseases.

"Type IV": A cohort phenomenon similar to Type III, but in Type IV the increase exists in almost all age groups, and the final age-specific death rate curve shows a slight slope in the figure. Therefore, the nature of the disease must be considered much more specific, and its particular etiology must be studied if we are to prevent diseases such as leukemia which is in this subcategory. This subcategory classification is illustrated in Fig. 10.

In general, the age-specific death rate curve should have a rectilinear pattern in the 

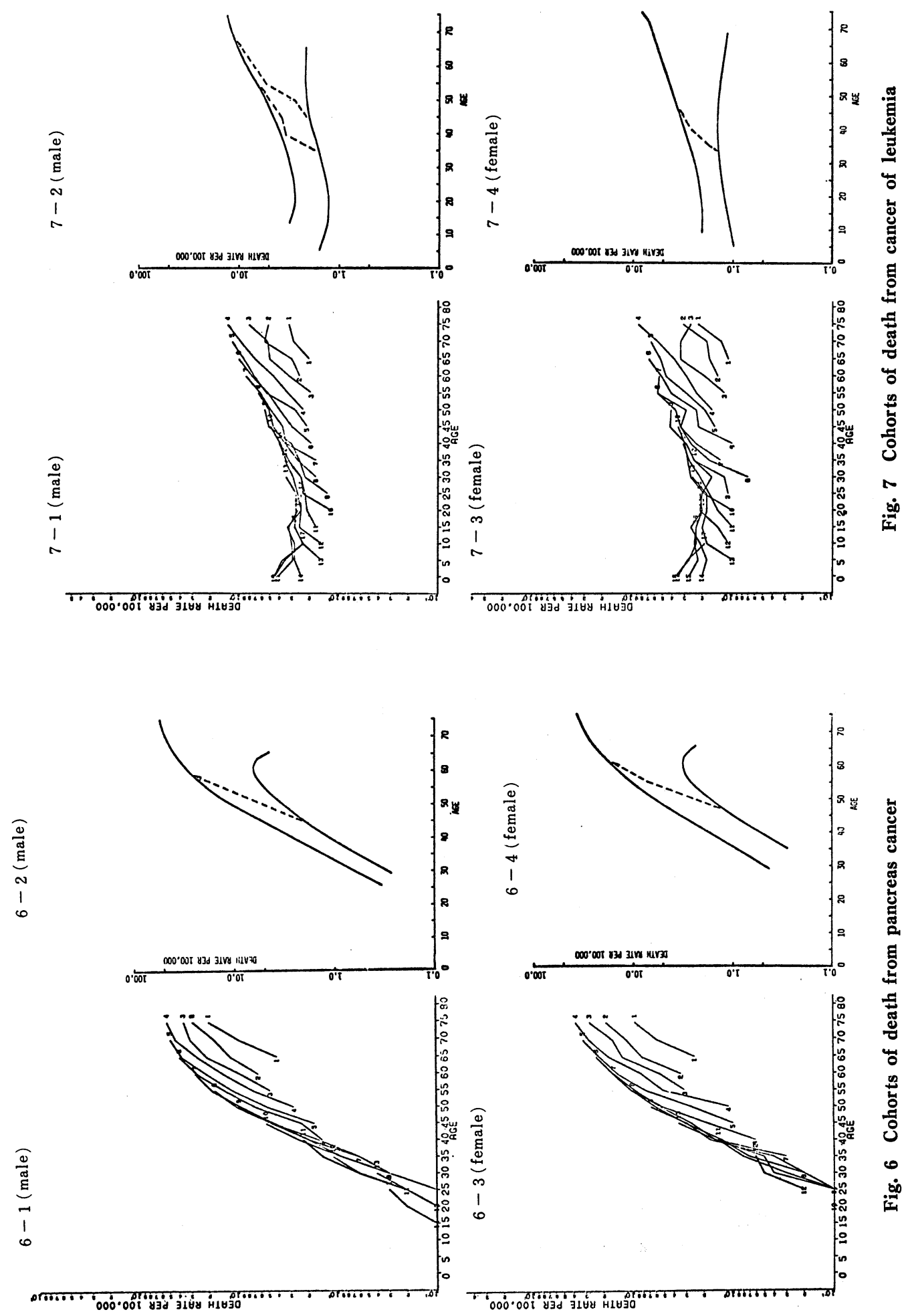


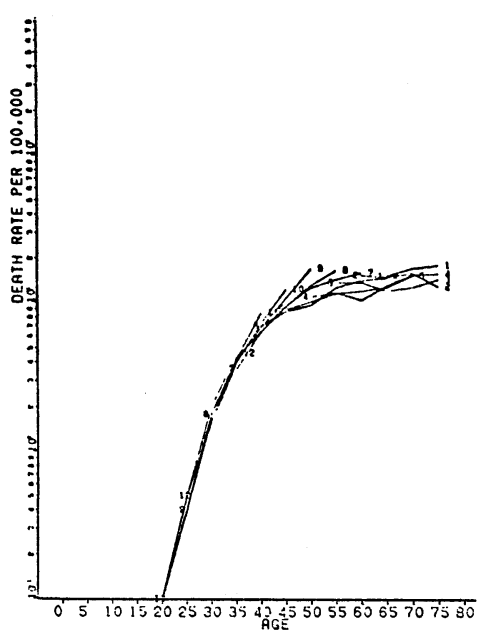

Fig. 8 Cohorts of death from cancer of breast (female)

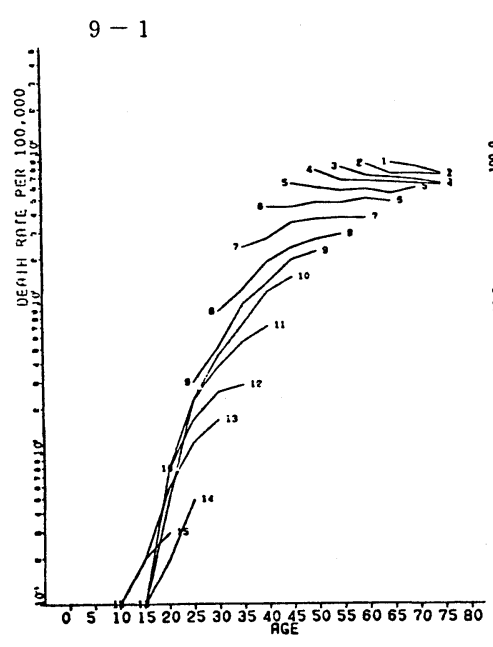

$9-2$

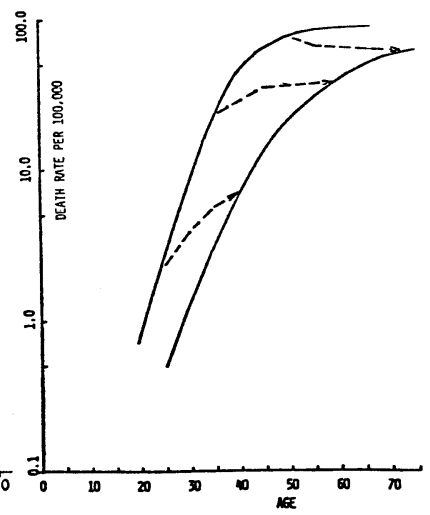

Fig. 9 Cohorts of death from cancer of uterus (female)

future, especially for those neoplasms for which the death rate is rather high at present. This is related to the nature of the disease. Diseases such as lung and pancreas cancers, would accentuate the nature of the so-called adult diseases. Conversely uterine and stomach cancers would be less characteristic adult diseases. Breast cancer is likely to continue in its current tendency.

\section{SUMMARY}

(1) Cohort analyses were made of the total and partial death rate for malignant neoplasms in both sexes.

(2) The cohort phenomenon was shown in the transition of the total death rate induced by malignant neoplasms in both sexes. The age-specific death rate curve forms a line similar to the rectilinear pattern seen in the

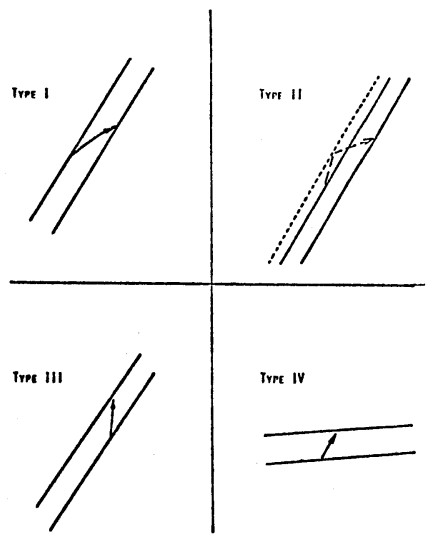

Fig. 10 Cohorts phenomena: schemata of category-I middle age groups and above.

(3) Decreasing cohort phenomena were seen in the uterine and stomach cancer analyses. Both forms of cancer are now on the decrease.

(4) Increasing cohort phenomena were demonstrated in the lung and pancreas cancer analyses for both sexes. The rate of increase has nearly reached zero, and the age-specific death rate curves are approximately straight lines.

(5) A two-phase cohort phenomenon was observed in the liver cancer analysis for females.

(6) The transition of the death rate for leukemia showed cohort phenomena for both sexes. However, a final age-specific death rate curve is being reached, and the nature of this disease has changed.

(7) The transition of the death rates for malignant neoplasms according to site can be classified as with and without cohort phenomena. Those that showed cohort phenomena can be classified into four types. 
a) The simple decreasing cohort phenomenon

b) The two-phase cohort phenomenon

c) The increasing cohort phenomenon that produces an age-specific death rate curve with a rectilinear pattern.

d) The increasing cohort phenomenon in all age groups.

(8) Suggestions for health control and related etiology were made in relation to the cohort phenomenon shown in malignant neoplasms.

\section{REFERENCES}

1) Lilienfeld, A. M. and Gifford, A. J.: Chronic Disease and Public Health, 321-488, The Johns Hopkins Press, Baltimore (1965).

2) Lilienfeld, A. M., Pedersen, E. and Dowd, J. E.: Cancer Epidemiology: Methods of Study, The Johns Hopkins Press, Baltimore (1967).

3) Program Committee, Cole, W. H. et al.: Cancer Management, J. B., Lippincott Co., Philadelphia (1968).

4) Schultze, H. E. and Heremans, J. F.: Molecular Biology of Human Proteins, Vol. I, E.P.C., Amsterdam (1966).

5) Green, H. N., Anthony, H. M., Baldwin, R. W. and Westrop, J. W.: An Immunological Approach to Cancer, Butterworths, London (1967).

6) Berenblum, I.: Carcinogenesis as a Biological Problem, North-Holland Pub. Co., Amsterdam-Oxford (1974).

7) Clemmesen, J.: Statistical Studies in the Aetiology of Malignant Neoplasms, Munksgaard, Kobenhavn (1965).

8) Akiyama, F. and Negishi, T.: Seijin Hoden Kanri, Kanehara Shuppan, Tokyo (1973). (in Japanese)

9) Ingram, J. T. and Comaish, S. : Ocupational Cancer of the Skin, Prevention of Cancer, 216-225, Butterworths. London (1967).

10) Parkes, H. G.: Industrial Aspects of Prevention of Cancer of the Bladder, Prevention of Cancer, 244248, Butterworths, London (1967).

11) Kessler, I. I. and Lilienfeld, A. M.: Perspectives in the Epidemiology of Leukemia, Advances in Cancer Research, 12, 225-302, Academic Press, New York (1960).

12) Yamagiwa, K. and Ichikawa, K.: Experimentelle Studie uber die Pathogenese der Epithelialgeschqulste, I, Mitteil. Med. Fakult. Kaiserl, Univ. Tokyo, 15, 296-333 (1915). (in German)

13) Cobb, L. M.: Trauma-Experimental Aspects, Prevention of Cancer, 43-46, Butterworths, London (1967).

14) Raven, R. W.: The Stomach-Experimental and Clinical Consideration, Prevention of Cancer, 103-113, Butterworths, London (1967).

15) Bonser, G. M.: Experimental Studies as a Background to the Prevention of Tumours of the Urinary Tract, Prevention of Cancer, 237-243, Butterworths, London (1967).

16) Waller, R. E.: Bronchi and Lungs. Air Pollution, Prevention of Cancer, 181-186, Butterworths, London (1967).

17) Ingram, J. T. and Comaish, S.: Skin Cancer from Actinic Exposure, Prevention of Cancer, 212-215, Butterworths, London (1967).

18) Nakayama, I.: Gendai Tokei-gaku Daijiten, 547-548, Toyokeizaishinposha, Tokyo (1962). (in Japanese)

19) Susser, M. and Stein, Z.: Civilisation and Peptic Ulcer, Lancet, 1, 115-119 (1962).

20) Frost, W. H.: The age selection of mortality from tuberculosis in successive decades, Am. J. Hyg., 30, 3, Sec. A, 91-96 (1939).

21) Tanaka, M.: Recent Chronological Changes in Death Rates from Tuberculosis in Japan, J. Kansai Md. Ass., 11, 3, 536-543 (1959). (in Japanese)

22) Doege, T. C.: Tuberculosis mortality in the United States, 1,900 to 1,060, J. Amer, Med. Assn., 192, 1045-1048 (1965).

23) Fox, J. P., Carrie, E. H. and Lila, R. E.: Epidemiology, Man and Disease, 239-265, The Macmillian Co., London (1970).

24) Nakazaki, K., Kitamura, K., Naito, M., Endo, Y. and Negishi, T.: Cohort Phenomena Shown on the Death Rate for Ischemic Heart Disease in Japan after World War II, Human Ecology and Race Hygiene, 42, 4, 171-182 (1976). (in Japanese) 
25) Nakazaki, K., Naito, M. and Negishi, T.: A Cohort Phenomenon of Death from Heart Disease in Japan, Human Ecology and Race Hygiene, 42, 3, 122-128 (1976). (in Japanese)

26) Hirotsu, M., Naito, M. and Negishi, T.: The Secular Trends in Death from Nephritis and Nephrosis as a Sign of the Pre-Urbanization of Modern Japan, Jap. J. Hgy., 32, 324 (1977). (in Japanese)

27) Nakazaki, K., Naito, M. and Negishi, T.: A Cohort Phenomenon of Ischemic Heart Disease in Japan, Jap. J. Pub. Health, 24, 10, 440 (1977). (in Japanese)

28) Miura, Y., Naito, M. and Negishi, T.: Cohort Phenomenon of Death from Diabetes Mellitus in Japan, Jap. J. Pub. Health, 24, 10, 331 (1977). (in Japanese)

29) Naito, M. and Negishi, T.: Cohort Phenomenon on Suicide in Japan, Jap. J. Pub. Health, 24, 10, 298 (1977). (in Japanese)

30) Negishi, T.: Cohort Analysis of Death Risk by Cause on Japanese Aged, International Congress of the Confederation of Medical Associations in Asia and Oceania, Tokyo (1977). (in Japanese)

31) Nodera, K.: Death from Peptic Ulcer and its Socio-economic and Cultural Background, Human Ecology and Race Hygiene. 43, 1, 2, 22-39 (1977). (in Japanese)

\section{悪性新生物死亡におけるコホート分析（日本）}

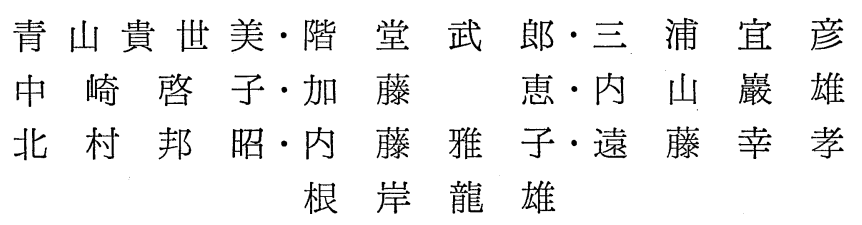

東京大学医学部成人保健学教室

わが国の悪性新生物死亡について，全部位および部位別に，性別・年㱓 5 歳階級別のコホート分析を行い，そ の動向を検討した。

資料は, 人口動態統計を用い, 各種演算は東京大学大型計算機センターHITAC 8800/8700システムによった。 作図は, X-Y プロッターを使用した。

1881年 1965年までの 5 年每の出生群を対象に, 横軸に年齢, 縦軸に人口 10 万対死亡率をとって, 経年的に変 化をみると, 全部位では, 高年層と若年層で, 後から生まれたコホートの死亡率上昇が認められた。ただし，女 子では, $40 \cdot 50$ 歳代で, 死亡率低下がみられた。

部位別にみると,コホート現象を示さぬすの（肝臟・男, 乳房・女）とコホート現象を示すむのに大別された。 さらに, コホート現象は 4 つの型に分類された。分類 1 は, 男女の胃の悪性新生物死亡にみられ, 後加ら出生 したコホート程, 同一年齢における死亡率が減少していく型である。

型 2 は, 型 1 の変型ともいえるすので, 一時期死亡率が上昇し, その後は型 1 と同様の減少を示す。 2 相性で あるととが特徵で, 女子の肝蔵の悪性新生物死亡に認められた。

型 3 は, 男女の肺の悪性新生物, 男女の膵臓の悪性新生物に代表されるすので, 出生の遅いコホートほど, 死 亡率の高まる現象を示している。乙れは, 型 1 とは逆の動きであり, 管理上, 重要な動向である。しかし, 若い コホートでは, 死亡率増加速度は減少しているので, 近い将来, ある一定の死亡率へ収束するすのと思われる。

型 4 は, 男女の白血病に認められた現象である。従来, 加齢とは余り関りのない死亡パターンであったものが, 全体的に死亡率が増加し，年龄階級別死亡率曲線が，高齢で高くなる方向に直線化，即ち非特異化の方向への死 亡構造の変化を示した。

（受付 1978年 8 月22日） 